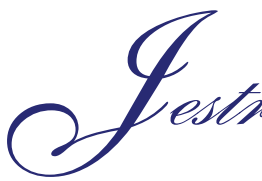

Journal of Engineering Science and Technology Review 3 (1) (2010) 108-110

JOURNAL OF

Engineering Science and

Technology Review

Research Article

www.jestr.org

\title{
Mineralogy in Geotechnical Engineering
}

\author{
A. Namdar
}

Mysore University, India.

Received 5 December 2009; Revised 24 March 2010; Accepted 30 April 2010

\begin{abstract}
The several investigations on soils by different researchers have been executed, but research on soil mechanical properties based on mineralogy is very meager, in this regard the author intention is employee of natural minerals for evaluation of soil cohesion, it may leads to developments of a soil with appropriates characteristics in permeability, transmitting load, resisting against deformation and settlement. This paper deals with analysis of soil cohesion based on mineralogy. The result revealed cohesion of a plastic soil could be improve by mineral presented in an non plastic soil, and also carbonate has negative affect on soil cohesion and some other soil minerals also have same affect on cohesion that required to be more investigate.
\end{abstract}

Keywords: Mixed Soil; Soil mineralogy; Carbonate.

\section{Introduction}

It is require analysis of soil cohesion based on consideration of soil mineralogy result. The soil cohesion is an element in controlling soil bearing capacity.

The soil bearing capacity could be determined by several methods like bearing capacity tables in various building codes, analytical methods, and plate bearing test, penetration test, model test, prototype tests and laboratory test [1-2]. There are several investigations on soil bearing capacity, use of soil in construction, ground improvement by mixed soil, mixing cement for modification of soil ability and effect of root in increasing slope stability [3-8]. The several investigations on soils have been done, but research on soil mechanical properties based on mineralogy is very meager, in this regard the author intention is employee of natural minerals for improving soil cohesion, it may leads to developments of a modified soil based on natural mineral.

\section{Methodology and Experiments}

To understanding of soil mechanical properties, results of XRD, direct shear test, liquid limit, and plastic limit and origin software were used, to evaluate of 16 mixed soil types under loose optimum moisture content (OMC) condition. The 16 mixed soil types from red plastic soil and black, green, dark brown, yellow and light brown non plastic soils (Table 1, Figure 1 and Table 2-3) were used to development of suitable mixed soil type based on studying soil mineralogy. The minerals presented in the soils were identified by use of the standard D-spacing and mineral intensity. Us-

*E-mail address: ab_namdar@yahoo.com

ISSN: 1791-2377 (C) 2010 Kavala Institute of Technology. All rights reserved. ing C, $\Phi$ and density values and adopting Terzaghi's method, the safe bearing capacity of the soil mixed models were calculated. In calculation of safe bearing capacity at all models has been assumed of $1.5 \mathrm{~m}$ depth and $2.5 \mathrm{~m} * 2.5 \mathrm{~m}$ widths for square footing, to improvement of site characteristics by select of different types of soils, which are consist of natural mineral, attempt was to find a scientific way to improve of soil characteristics and it could be lead to construct of better earth structure and soil foundation.

Table 1. Mixed soil types [9].

\begin{tabular}{ccccccc}
\hline $\begin{array}{c}\text { Model } \\
\text { No }\end{array}$ & $\begin{array}{c}\text { \% Of } \\
\text { Red } \\
\text { Soil }\end{array}$ & $\begin{array}{c}\text { \% Of } \\
\text { Black } \\
\text { Soil }\end{array}$ & $\begin{array}{c}\text { \% Of } \\
\text { Green } \\
\text { Soil }\end{array}$ & $\begin{array}{c}\text { \% Of } \\
\text { Dark } \\
\text { Brown Soil }\end{array}$ & $\begin{array}{c}\text { \%ellow } \\
\text { Soil }\end{array}$ & $\begin{array}{c}\text { \% Of Light } \\
\text { Brown Soil }\end{array}$ \\
\hline 1 & 100 & 0 & 0 & 0 & 0 & 0 \\
2 & 55 & 0 & 0 & 0 & 0 & 45 \\
3 & 55 & 45 & 0 & 0 & 0 & 0 \\
4 & 55 & 0 & 45 & 0 & 0 & 0 \\
5 & 55 & 0 & 0 & 45 & 0 & 0 \\
6 & 55 & 0 & 0 & 0 & 45 & 0 \\
7 & 90 & 2 & 2 & 2 & 2 & 2 \\
8 & 80 & 4 & 4 & 4 & 4 & 4 \\
9 & 70 & 6 & 6 & 6 & 6 & 6 \\
10 & 60 & 8 & 8 & 8 & 8 & 8 \\
11 & 50 & 10 & 10 & 10 & 10 & 10 \\
12 & 70 & 10 & 10 & 10 & 0 & 0 \\
13 & 70 & 10 & 10 & 0 & 10 & 0 \\
14 & 70 & 10 & 10 & 0 & 0 & 10 \\
15 & 70 & 10 & 0 & 10 & 10 & 0 \\
16 & 70 & 10 & 0 & 10 & 0 & 10 \\
\hline
\end{tabular}


Table 2. Result of liquid limit of red soil [11].

\begin{tabular}{ccccccccc}
\hline Sl. & $\begin{array}{c}\text { Read- } \\
\text { ing } \\
\text { num- } \\
\text { ber }\end{array}$ & $\begin{array}{c}\text { Cup } \\
\text { num- } \\
\text { ber }\end{array}$ & $\begin{array}{c}\text { Weight } \\
\text { of wet } \\
\text { sample } \\
\text { (Gram) }\end{array}$ & $\begin{array}{c}\text { Weight } \\
\text { of dry } \\
\text { sample } \\
\text { (Gram) }\end{array}$ & $\begin{array}{c}\text { Weight } \\
\text { of cup } \\
\text { (Gram) }\end{array}$ & $\begin{array}{c}\text { Weight } \\
\text { of dry } \\
\text { soil } \\
\text { (Gram) }\end{array}$ & $\begin{array}{c}\text { Weight } \\
\text { of } \\
\text { water } \\
\text { (Gram) }\end{array}$ & $\begin{array}{c}\text { \% Of } \\
\text { water }\end{array}$ \\
\hline 1 & 16 & 75 & 39.7 & 35.43 & 23.24 & 12.19 & 4.27 & 35.02 \\
2 & 22 & 41 & 37.6 & 34.11 & 23.89 & 10.22 & 3.49 & 34.14 \\
3 & 28 & 103 & 34.92 & 32 & 23.4 & 8.6 & 2.92 & 33.85 \\
4 & 33 & 61 & 37.7 & 33.83 & 22.42 & 11.41 & 3.87 & 33.91 \\
5 & 39 & 1 & 51.14 & 48.24 & 39.11 & 9.13 & 2.9 & 33.76 \\
\hline
\end{tabular}

Table 3. Result of liquid plastic of red soil [11].

\begin{tabular}{ccccccccc}
\hline SI. & $\begin{array}{c}\text { Cup } \\
\text { num- } \\
\text { ber }\end{array}$ & $\begin{array}{c}\text { Weight } \\
\text { of wet } \\
\text { sample } \\
\text { (Gram) }\end{array}$ & $\begin{array}{c}\text { Weight } \\
\text { of dry } \\
\text { sample } \\
\text { (Gram) }\end{array}$ & $\begin{array}{c}\text { Weight } \\
\text { of cup } \\
\text { (Gram) }\end{array}$ & $\begin{array}{c}\text { Weight } \\
\text { of } \\
\text { Water } \\
\text { (Gram) }\end{array}$ & $\begin{array}{c}\text { Weight } \\
\text { of dry } \\
\text { soil } \\
\text { (Gram) }\end{array}$ & $\begin{array}{c}\text { \% of } \\
\text { water }\end{array}$ & $\begin{array}{c}\text { Plastic } \\
\text { limit } \\
\text { \% }\end{array}$ \\
\hline 1 & 86 & 25.75 & 25.20 & 22.68 & 0.46 & 2.61 & 17.62 & 17.785 \\
5 & 7 & 39.55 & 39.11 & 36.66 & 0.44 & 2.45 & 17.95 & \\
\hline
\end{tabular}

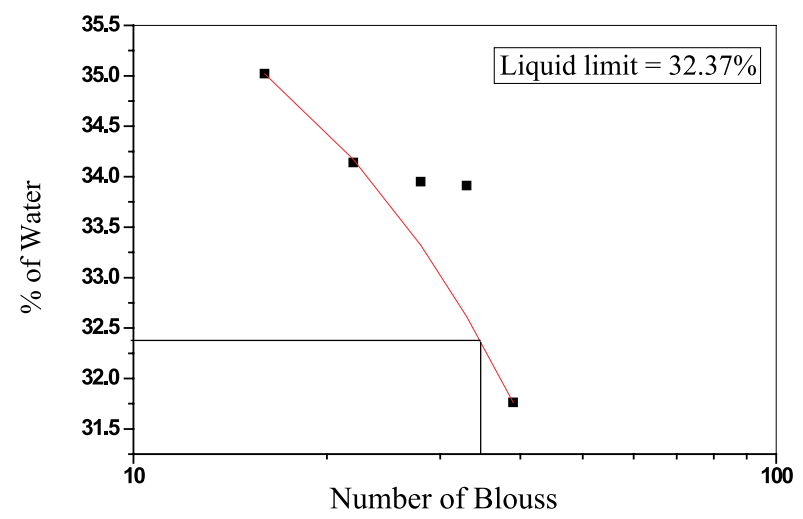

Figure 1. Result of liquid limit of red soil [11]

\section{Results and Discussion}

Form different studies it is understood that the mixed soil is a technique for improving soil foundation, slope, embankment, pavement and etc. The soil cohesion decreases continuously with reduction of clay minerals in the soil. On the other hand, not many experimental studies have been made to assess the micro behavior of soil mechanical properties in geotechnical engineering. It is also not known from the available literature, either from any experimental study or from the theory, about the effect of the clay mineral presented in non plastic soil and employee of that for increasing plasticity in plastic soil. This is the motive of the present research work. It is aimed to developing a series of the mixed soil types on assessing the behavior of the some clay mineral in acceleration of soil cohesion. It should be mentioned that the experiments on the mixed soil types provide quite an accurate way to assess the response of the plastic soil under different clay mineral. In addition, it will also be intended, with the help of a rigorous computational model, by using the bearing capacity calculation method could be find acceptability of this method for applying in construction industry.

The purpose of the entire research exercise would be to predict the response of the soil mineral for accelerating of soil cohesion and improving of soil bearing capacity.
To investigation of mixed soil bearing capacity when it is under loose OMC condition (Table 4 and figure 2) the minerals of the soils which are, muscovite, biotite, carbonates and fluorapatite, illite, saponite, sauconite, pyrophyllite, orthochamosite, brucite, clinochlore, nacrite, odinite, amesite, chamosite, cancrisilite, chamosite and orthochamosite evaluated (Table 5), obviously in the practical never using loose soil but due to objective of investigation for clarifying positive and negative affect of minerals loose mixed soil has been selected.

In this investigation main objective is evaluation of affect of all minerals in cohesion soil especially clay mineral presented in the non plastic soil, in this regard for test of reasoning the compaction technique has not been used for clearly understanding mineral action on soil cohesion, in these mixed soil types the only red soil was plastic but clay mineral of non plastic soil accelerated of mixed soil plasticity, it could be mentioned any amount of clay mineral even in the non plastic soil could be used in mixed soil technique to improvement of cohesion.

Table 4. Mixed soil type under loose \& optimummoisture content (OMC) condition [10].

\begin{tabular}{cccccc}
\hline $\begin{array}{c}\text { Model } \\
\text { No }\end{array}$ & $\begin{array}{c}\text { Optimum Mois- } \\
\text { ture Content } \mathbf{( \% )}\end{array}$ & $\begin{array}{c}\gamma_{\mathbf{d}}(\mathbf{K N} / \\
\left.\mathbf{m}^{3}\right)\end{array}$ & $\begin{array}{c}\mathbf{\Phi} \\
\text { Degree }\end{array}$ & $\begin{array}{c}\mathbf{C} \\
\left(\mathbf{K N} / \mathbf{m}^{2}\right)\end{array}$ & $\begin{array}{c}\text { S. B. C } \\
\left(\mathbf{K N} / \mathbf{m}^{2}\right)\end{array}$ \\
\hline 1 & 11.2 & 10.8 & 27 & 10 & 279.61 \\
2 & 14.56 & 11.2 & 26 & 2 & 336.07 \\
3 & 22.39 & 11.35 & 24 & 6 & 171.96 \\
4 & 18.86 & 11.62 & 31 & 4 & 324.93 \\
5 & 14.56 & 14.41 & 20 & 10 & 157.56 \\
6 & 14.23 & 11.08 & 28.5 & 10 & 326.59 \\
7 & 16.83 & 10.11 & 32 & 10 & 445.97 \\
8 & 18.27 & 10.6 & 25 & 8 & 199.20 \\
9 & 16.76 & 11.8 & 20 & 24 & 243.72 \\
10 & 20.21 & 12.23 & 17 & 14.5 & 142.12 \\
11 & 18.68 & 11.2 & 21 & 14 & 178.69 \\
12 & 19.34 & 11.5 & 21 & 10 & 166.03 \\
13 & 16.55 & 9.99 & 23.5 & 20 & 291.38 \\
14 & 21.14 & 11.27 & 18 & 19 & 191.16 \\
15 & 20.79 & 12.89 & 13 & 20 & 145.73 \\
16 & 16.31 & 10.05 & 26.5 & 8 & 230.78 \\
\hline
\end{tabular}

Table 5. Minerals of Soil Sample [9].

\begin{tabular}{|c|c|c|}
\hline $\begin{array}{l}\text { Sl. } \\
\text { No }\end{array}$ & Soil Name & Minerals in the soil sample \\
\hline 1 & Red soil & $\begin{array}{l}\text { quartz, illite, muscovite, saponite, sauconite and } \\
\text { carbonate- fluorapatite }\end{array}$ \\
\hline 2 & Black soil & $\begin{array}{c}\text { quartz, pyrophyllite, carbonate- fluorapatite and } \\
\text { orthochamosite }\end{array}$ \\
\hline 3 & Yellow soil & quartz, brucite, clinochlore and sandoite \\
\hline 4 & Light brown soil & quartz and carbonate \\
\hline 5 & Dark brown soil & nacrite, odinite, amesite, chamosite and biotite \\
\hline 6 & Green soil & $\begin{array}{c}\text { quartz, cancrisilite, chamosite, orthochamosite and } \\
\text { brucite }\end{array}$ \\
\hline
\end{tabular}




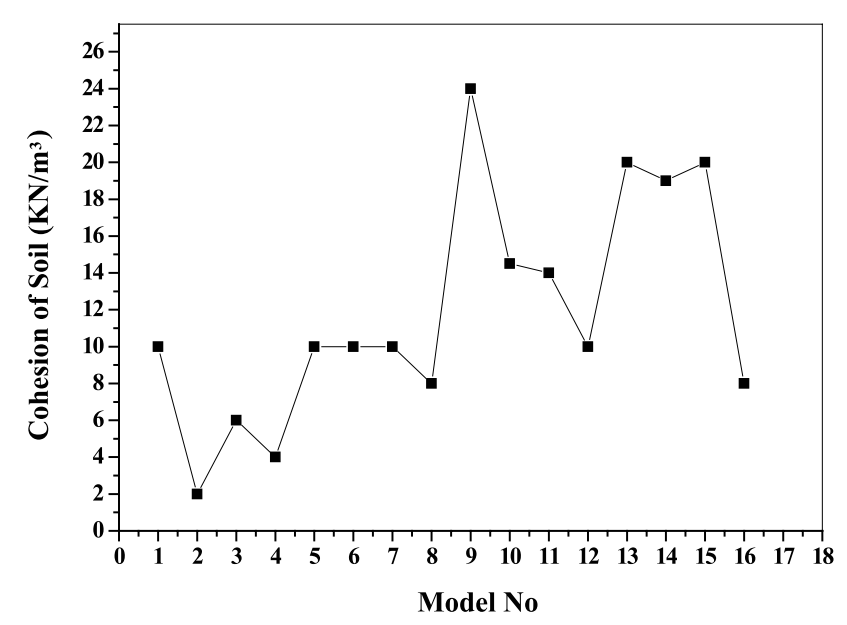

Figure 2. Cohesion of Soil Vs Model No

Form the evaluation of mixed soil types 2 (consist of $55 \%$ red soil and $45 \%$ of light brown soil), mixed soil types 3(made up from $55 \%$ of red soil and $45 \%$ of black soil) and mixed soil types 4 (developed from $55 \%$ red soil and $45 \%$ of green soil) which are with lowest cohesion and from mineralogy evaluation of these three mixed soil types could be conclude the mixed soil types 2 and 3 due to availability of carbonate mineral could be observed of significantly reducing soil cohesion and in the mixed soil type 4 also one or more minerals presented in the green soil which have negative affected on the soil cohesion, and in this regard could be investigate later.

The one of the most important challenge of geotechnical engineering is always faces is rising underground water and mixing mineral in the water and reached those to the soil foundation, this could lead to negative impose on the soil mechanical properties, it could be think over the filtering the area may be affected by help of other mineral or any other method of filtering.

The liquefaction is one of the important phenomenon which occur due to earthquake when underground water is near the surface in the sandy subsoil in this phenomenon the soil cohesion tend to be zero, from the results appeared in this investigation could be conclude if minerals which are have negative affect on the soil cohesion, this is content in under ground water it will accelerate the reduction of soil cohesion and also it is possibility to mitigation of liquefaction using some kind of minerals, It may be possible by injection of some minerals to the soil foundation for decreasing affect of liquefaction or improving of soil foundation even in absent of liquefaction. The second suggestion could be mention is in the time of compacting soil for achieving better result adding mineral to the soil trough the water is also a way of increasing soil strength.

\section{Conclusion}

1. The illite, muscovite, saponite, sauconite presented in the red plastic soil play main factors in soil cohesion as remaining clay minerals in other soils, when mixed with red soil accelerating soil cohesion

2. The carbonate has negative in soil cohesion which other mineral may be similar in the green soil

3. Appropriate collecting or interacting between soil mineral in a mixed soil type could developing natural safe subsoil and or leads to creating suitable foundation for a structure based not using reinforcement concrete

4. The investigation has possibilities for optimization of the ground improvement in the real project. The technique could be resulted in safer and economical construction activities.

\section{Nomenclature}

$\begin{array}{ll}\Phi[\circ] & =\text { Friction Angle } \\ \mathrm{C}\left[\mathrm{kN} / \mathrm{m}^{2}\right] & =\text { Soil Cohesion } \\ \mathrm{OMC} & =\text { Optimum Moisture Content } \\ \mathrm{SBC}\left[\mathrm{kN} / \mathrm{m}^{2}\right] & =\text { Safe Bearing Capacity } \\ \gamma_{\mathrm{d}}\left[\mathrm{kN} / \mathrm{m}^{3}\right] & =\text { Unit Weight }\end{array}$

\section{References}

1. C. Venkatramaiah (1993), Geotechnical engineering, third edition, New Delhi: John Wiley Eastern.

2. V. S. Murthy (2002), Geotechnical Engineering, Published by CRC Press.

3. J. Prabakar et al. (2004), Influence of fly ash on strength behavior of typical soils, Construction and Building Materials, Vol. 18, Issue 4.

4. Md. Shahidul Islam et al. (2009), Bearing Capacity of Stabilised Tropical Peat by Deep Mixing Method, Australian Journal of Basic and Applied Sciences, 3(2), pp. 682-688.

5. Hebib, S. et al. (2003), Some experiences on the stabilization of Irish peats, Can. Geotech. J. 40, pp. 107-102.

6. Behzad Kalantari et al. (2009), Load-Bearing Capacity Improvement for Peat Soil, European Journal of Scientific Research, Vol. 32, No. 2
7. R. Hashim et al. (2008), A Model Study to Determine Engineering Properties of Peat Soil and Effect on Strength after Stabilization, Journal of Scientific Research Vol.22, No.2.

8. www.Greenbeltconsulting.com

9. A. Namdar (2009), Identification of Mixed Soil Characteristics by Application of Laboratory Test, EJGE, Vol. 14, Bund. B.

10. A. Namdar et al. (2009), Bearing and liquefaction evaluation of mixed soils, Ingenierías, Vol. XII, No. 44.

11. A. Namdar et al. (2009), Bearing capacity of mixed soil model, Frattura ed Integrità Strutturale, 7, 73-79; DOI: 10.3221/IGF-ESIS.07.06 